Note

\title{
Enzymatic Production of $N$-Acetyl-D-Glucosamine Using Crude Enzyme from the Liver of Squids
}

\author{
Masahiro MATSUMIYA \\ Department of Marine Science and Resources, College of Bioresource Sciences, Nihon University, 1221-9 Kameino, \\ Fujisawa, Kanagawa 252-8510, Japan
}

Received December 22, 2003; Accepted March 25, 2004

\begin{abstract}
Enzymatic production of $N$-acetyl-D-glucosamine (GlcNAc) from chitin was investigated using crude enzyme from the liver of Japanese common squid Todarodes pacificus and cuttlefish Sepia esculenta. The ratio for the activities of endo- and exo-type chitinolytic enzyme, chitinase and $\beta$ - $N$-acetylhexosaminidase, in the crude enzyme prepared from the liver of Japanese common squid was 1:19 and those of cuttlefish was 1:20. Both enzyme activities from cuttlefish were about 1.5 time higher than those of Japanese common squid. Crude enzyme of Japanese common squid, corresponding to $2 \mathrm{~g}$ of liver weight, produced $26.8 \mathrm{mg}$ of reducing sugar from $50 \mathrm{mg}$ of colloidal chitin during 5 days of incubation at $37^{\circ} \mathrm{C}$. In the crude enzyme from cuttlefish, $44.4 \mathrm{mg}$ of reducing sugar was obtained under the same reaction conditions. The main product of the produced reducing sugar, analyzed by HPLC, was GIcNAc. These results suggest that squid liver could be a source of chitinolytic enzyme for the enzymatic production of GlcNAc.
\end{abstract}

Keywords: $N$-acetyl-D-glucosamine, chitinase, $\beta$ - $N$-acetylhexosaminidase, squid liver, enzymatic production.

$\mathrm{N}$-acetyl-D-glucosamine (GlcNAc) is a monosaccharide found in chitin, which is one of the world's most abundant biomasses second only to cellulose. Although chitin is an insoluble polymer known to be a major structural component of crustacean shells, insect exoskeletons, and fungal cell walls, GlcNAc has water solubility and some physiological functions (Kikuchi, 2001). Moreover, recently, GlcNAc has been investigated intensively for the treatment of osteoarthritis (Matahira, 1999; Kikuchi, 2001) similar to D-glucosamine (GlcN) hydrochloride or sulfate, which have been already commercialized as a food supplement (Kajimoto et al., 1998; Suguro et al., 2000), because GlcNAc and GlcN are components of proteoglycan in cartilage. GlcN salts have a bitter taste, but GlcNAc has a sweet taste, $55 \%$ compared to sucrose. For this reason, GlcNAc is a suitable functional material with sweetness for the food industry. GlcNAc is produced from GlcN by $\mathrm{N}$-acetylation, however, this product is not approved as a natural material which can be used as a food additive. Recently, some enzymatic methods of producing GlcNAc from chitin have been reported (Sashiwa et al., 2001, 2002, 2003; Pichyangkura et al., 2002; Sukwattanasinitt et al., 2002). Those reports used commercial non-chitinase crude enzyme produced from microorganisms such as cellulase for hydrolysis of chitin, because commercial non-chitinase crude enzymes include both endo- and exo-type chitinolytic enzymes, chitinase (EC 3.2.1.14) and $N$-acetylhexosaminidase (EC

E-mail: matsumiya@brs.nihon-u.ac.jp
3.2.1.52), respectively. Moreover, non-chitinase crude enzyme is much cheaper than pure chitinolytic enzyme.

The current author previously reported the presence of endo- and exo-type chitinolytic enzymes in the liver of a few squid (Matsumiya et al., 1998, and also purified and characterized the chitinase isozymes from the liver of Japanese common squid (Matsumiya et al., 1997, 2002, 2003). The chitinase isozymes showed hydrolyzing activity toward insoluble chitin. This study reports the enzymatic production of GlcNAc by crude enzyme prepared from the liver of Japanese common squid and cuttlefish in order to effectively use the organs obtained during marine food processing.

\section{Materials and Methods}

Materials Fresh Japanese common squid Todarodes pacificus (number of samples: 3, average body weight: 195 g, average liver weight: $19 \mathrm{~g}$ ) and cuttlefish Sepia esculenta (number of samples: 1, body weight: 1,770 g, liver weight: $112 \mathrm{~g}$ ) were purchased from Tokyo Wholesale Fish Market in May, 2002. Glycol chitin, $N$-acetylchitooligosaccharides ( $\mathrm{GlcNAc}_{\mathrm{n}}, n=1$ to 6 ), and $p$-nitrophenyl $N$-acetylglucosaminide (pNp-GlcNAc) were purchased from Seikagaku Kogyo Co. Chitin (crab shell chitin) was obtained from Tokyo Kasei Co., Ltd. Colloidal chitin was prepared by the method of Ohtakara et al. (1991). All other chemicals were of high grade.

Measurement of chitinolytic enzyme activity Chitinase activity was assayed according to the method described by Imoto and Yagishita (1971) by measuring the amount of reducing sugar produced by an enzyme reaction with glycol 
chitin as substrate. One milliliter of $0.1 \mathrm{M}$ sodium acetate

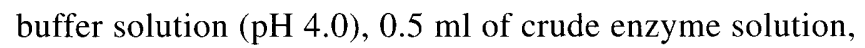
and $1 \mathrm{ml}$ of $0.05 \%(\mathrm{w} / \mathrm{v})$ glycol chitin solution were incubated for $30 \mathrm{~min}$ at $37^{\circ} \mathrm{C}$. After the enzyme reaction was completed, $2 \mathrm{ml}$ of Schales' reagent $(0.5 \mathrm{M}$ sodium carbonate solution containing $0.05 \%$ potassium ferricyanide) was added to the solution to stop the reaction. The solution was then heated in a boiling water bath for $15 \mathrm{~min}$. After cooling under running water, absorbency was measured at $420 \mathrm{~nm}$. The value recorded was converted into an amount of GlcNAc by the standard curve prepared using GlcNAc. Measurement of $\beta$ - $N$-acetylhexosaminidase activity was made according to the method prescribed by Ohtakara (1988) using pNpGlcNAc as substrate. Five-tenths milliliter of crude enzyme solution and $0.2 \mathrm{ml}$ of $4 \mathrm{mM} \mathrm{pNp}-\mathrm{GlcNAc}$ were added to $0.5 \mathrm{ml}$ of $0.2 \mathrm{M}$ phosphate- $0.1 \mathrm{M}$ citrate buffer solution $(\mathrm{pH}$ 4.5). The mixture was then reacted for $10 \mathrm{~min}$ at $37^{\circ} \mathrm{C}$. The reaction was stopped by adding $2 \mathrm{ml}$ of $0.2 \mathrm{M}$ sodium carbonate, and then absorbency was measured at 420 $\mathrm{nm}$. The value recorded was converted into an amount of $p$-nitrophenol by the standard curve prepared using $p$-nitrophenol.

HPLC analysis A $20 \mu$ portion of the reaction mixture was injected into a Waters $\mu$ Bondasphere $5 \mu \mathrm{NH}_{2} 100 \AA$ column $(3.9 \times 150 \mathrm{~mm})$ and eluted with $70 \%$ acetonitrile at $1.0 \mathrm{ml} / \mathrm{min}$. The $\mathrm{GlcNAc}_{\mathrm{n}}$ eluted was monitored at $210 \mathrm{~nm}$.

Determination of protein Protein concentration was determined by the method of Bardford (1976) with bovine serum albumin as the standard protein.

Preparation of crude enzyme The liver was collected and ground uniformly in a mortar. Forty grams of ground liver was homogenized with $200 \mathrm{ml}$ of $10 \mathrm{mM}$ sodium acetate buffer ( $\mathrm{pH}$ 6.0). The homogenate was centrifuged at $10,000 \times \mathrm{g}$ for $20 \mathrm{~min}$. The supernatant was filtered through two layers of gauze to remove floating fat and used as the crude extract. Ammonium sulfate was added to the crude extract up to $65 \%$ saturation and left to stand for 1 day at $4^{\circ} \mathrm{C}$. The precipitate was collected by centrifugation at $10,000 \times \mathrm{g}$ for $20 \mathrm{~min}$, then was dissolved in a small volume of $10 \mathrm{mM}$ sodium acetate buffer ( $\mathrm{pH} \mathrm{6.0)}$ and dialyzed against the same buffer. The dialyzate was centrifuged at $10,000 \times \mathrm{g}$ for $20 \mathrm{~min}$ to remove insoluble material and the supernatant was used as the crude enzyme.

Hydrolysis of chitin by crude enzyme The typical procedure follows: $10 \mathrm{ml}$ of $0.5 \%$ colloidal chitin suspension (50 mg of colloidal chitin), $20 \mathrm{ml}$ of $0.1 \mathrm{M}$ sodium acetate buffer ( $\mathrm{pH} \mathrm{4.0)}$ ), and $10 \mathrm{ml}$ of crude enzyme solution (corresponding to $2 \mathrm{~g}$ of liver) were incubated at $37^{\circ} \mathrm{C}$ with agitation. After the prescribed time, $3.5 \mathrm{ml}$ of reaction mixture was removed, heated in a boiling water bath for 5 min, and filtered through filter paper. The amount of reducing sugar in the filtrate was measured by Schales' reagent described above, and converted into an amount of GlcNAc. When $200 \mathrm{mg}$ of colloidal chitin was used for the reaction, $10 \mathrm{ml}$ of $2.0 \%$ colloidal chitin suspension was used instead of $10 \mathrm{ml}$ of $0.5 \%$ colloidal chitin suspension.

\section{Results and Discussion}

Chitinolytic enzyme activity To know the endo- and exo-type chitinolytic enzyme activities, chitinase and $\beta-N$ acetylhexosaminidase activities in the crude enzyme prepared from the liver of Japanese common squid and cuttlefish were measured. As shown in Table 1, both enzyme activities were detected in the crude enzymes, and the ratio of the activity of chitinase and $\beta-N$-acetylhexosaminidase in the crude enzyme was 1:19 for Japanese common squid and 1:20 for cuttlefish. These results were very different from the chitinolytic enzyme activities in the commercial cellulases, which show higher chitinase activity than $\beta-N$ acetylhexosaminidase (Sashiwa et al., 2003). On the other hand, chitinase and $\beta$ - $N$-acetylhexosaminidase activities of cuttlefish were 1.4 and 1.5 times higher than those of Japanese common squid. Protein content in the crude enzyme from cuttlefish was about 1.9 times higher than that from Japanese common squid. Therefore, the specific activities of both enzymes in the cuttlefish were slightly lower than that of Japanese common squid.

Table 1. Chitinolytic enzyme activity in crude enzyme prepared from squid liver.

\begin{tabular}{lcc}
\hline \multirow{2}{*}{ Squid } & \multicolumn{2}{c}{ Activity $(\mu \mathrm{mol} / \mathrm{g} / \mathrm{min})$} \\
\cline { 2 - 3 } & Chitinase & $\beta$ - $N$-acetylhexosaminidase \\
\hline Japanese common squid & 0.058 & 1.09 \\
(Todarodes pacificus) & $(1)^{*}$ & $(19)^{*}$ \\
Cuttlefish & $(0.011)^{* *}$ & $(0.210)^{* *}$ \\
(Sepia esculenta) & 0.081 & 1.65 \\
& $(1)^{*}$ & $(20)^{*}$ \\
& $(0.0083)^{* *}$ & $(0.169)^{* *}$ \\
\hline
\end{tabular}

*Enzyme activity ratio of chitinase to $\beta$ - $N$-acetylhexosaminidase. $* *$ Specific activity $(\mu \mathrm{mol} / \mathrm{mg}$ prot $/ \mathrm{min})$. Protein content of crude enzyme: $5.18 \mathrm{mg}$ protein/g in Japanese common squid liver. $9.76 \mathrm{mg}$ protein/g in cuttlefish liver.

Hydrolysis of chitin by crude enzyme In the previous paper, the author reported that the stable $\mathrm{pH}$ and optimal $\mathrm{pH}$ for colloidal chitin were $\mathrm{pH} 4-6$ and 3.0 for the $38 \mathrm{kDa}$ chitinase, and $\mathrm{pH} 4-5$ and 3.0 for the $42 \mathrm{kDa}$ chitinase in the liver of Japanese common squid (Matsumiya et al., 1997, $2002,2003)$. In order to determine those values of $\beta-N$ acetylhexosaminidase, both $\mathrm{pHs}$ were measured using crude enzyme from the liver of Japanese common squid. The enzyme was stable at $\mathrm{pH} 4-6$ (data not shown). As shown in Fig. 1 , the optimal $\mathrm{pH}$ of $\beta$ - $N$-acetylhexosaminidase was 4.5 with $80 \%$ of the maximal activity at $\mathrm{pH} 4.0$. The optimal $\mathrm{pH}$ of $\beta$ - $N$-acetylhexosaminidase from the liver of cuttlefish was also measured, and was found to be 4.5 , the same as Japanese common squid. However, the enzyme showed more than $80 \%$ of the maximal activity from $\mathrm{pH} 3.0$ to 6.5 . This result means that $\beta-N$-acetylhexosaminidase from cuttlefish is active over a wide range of $\mathrm{pH}$. Based on these results, hydrolysis of colloidal chitin was performed at $\mathrm{pH}$ 4.0 , which is a stable $\mathrm{pH}$ for all the chitinolytic enzymes and is the medium to optimal $\mathrm{pH}$ for endo- and exo-type chitinolytic enzymes. Figure 2 shows the production of reducing sugar during the reaction. After one day of incu- 


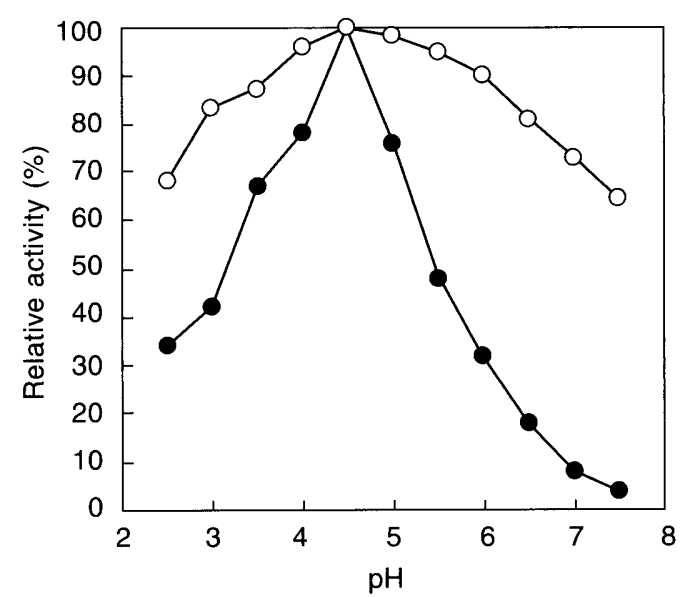

Fig. 1. Effect of $\mathrm{pH}$ on $\beta-N$-acetylhexosaminidase activity of crude enzyme from the liver of squids. Enzyme activity was measured with $0.2 \mathrm{M}$ phosphate $-0.1 \mathrm{M}$ citrate buffer solution $(\mathrm{pH} 2.5-7.5)$ for $10 \mathrm{~min}$ at $37^{\circ} \mathrm{C}$. Japanese common squid, $O$ : cuttlefish.

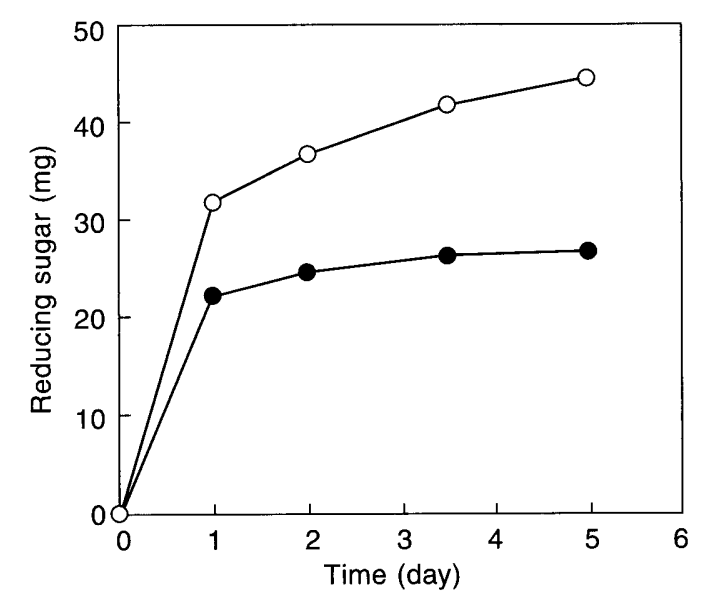

Fig. 2. Time course on the production of reducing sugar from colloidal chitin by chitinolytic enzyme from the liver of squids. Japanese common squid, O: cuttlefish.

bation, $22.3 \mathrm{mg}$ and $31.8 \mathrm{mg}$ of reducing sugar was produced by enzymatic reaction by crude enzyme from Japanese common squid and cuttlefish, respectively. The amount of reducing sugar produced from day 1 to day 5 increased slowly and reached $26.8 \mathrm{mg}$ and $44.4 \mathrm{mg}$ at day 5 , respectively. The ratio of amount of reducing sugar produced using cuttlefish crude enzyme was about 1.7 times higher than that using Japanese common squid, due to the difference of chitinolytic enzyme activity, shown in Table 1, and stability of the chitinolytic enzymes during incubation. Next, the effect of the amount of colloidal chitin on the production of reducing sugar was investigated using 200 $\mathrm{mg}$ of colloidal chitin for the reaction. After five days of incubation, $27.5 \mathrm{mg}$ and $45.7 \mathrm{mg}$ of reducing sugar was produced by enzymatic reaction by the enzyme from Japanese common squid and cuttlefish, respectively. These values were approximately equal to that of $50 \mathrm{mg}$ of colloidal chitin, $26.8 \mathrm{mg}$ and $44.4 \mathrm{mg}$. Therefore, it seems that the amount of reducing sugar produced depends on the amount of chitinolytic enzyme under this reaction condition.
To investigate the composition of the reaction product, HPLC analysis was done as described in Materials and Methods. An HPLC chromatogram of the hydrolysate of colloidal chitin $(50 \mathrm{mg})$ by chitinolytic enzyme from the liver of Japanese common squid at $37^{\circ} \mathrm{C}$ for 24 hours is shown in Fig. 3. The main product of the reducing sugar produced, with a retention time of $3.4 \mathrm{~min}$, was GlcNAc Colloidal chitin containing a small portion of glucosamine $(\mathrm{GlcN})$, was produced by deacetylation of GlcNAc during processes of chitin purification and colloidal chitin preparation. Other minoer peaks may therefore be hetero oligomers which contain GlcN. In the previous paper (Matsumiya et al., 2002), it was reported that the 38 and $42 \mathrm{kDa}$ chitinase isozymes from the liver of Japanese common squid cleaved GlcNAc $n$ ( $n=4$ to 6) to $\mathrm{GlcNAc}_{2}$ or $\mathrm{GlcNAc}_{3}$. This result showed that dimeric or trimeric GlcNAc produced from colloidal chitin by hydrolysis of squid liver chitinase, was in turn further hydrolyzed by $\beta$ $N$-acetylhexosaminidase to GlcNAc. The activity of $\beta-\mathrm{N}$ acetylhexosaminidase was about 20 times higher than those of chitinase for both squids. This value was much higher than commercial bacterial enzymes like cellulases (Sashiwa

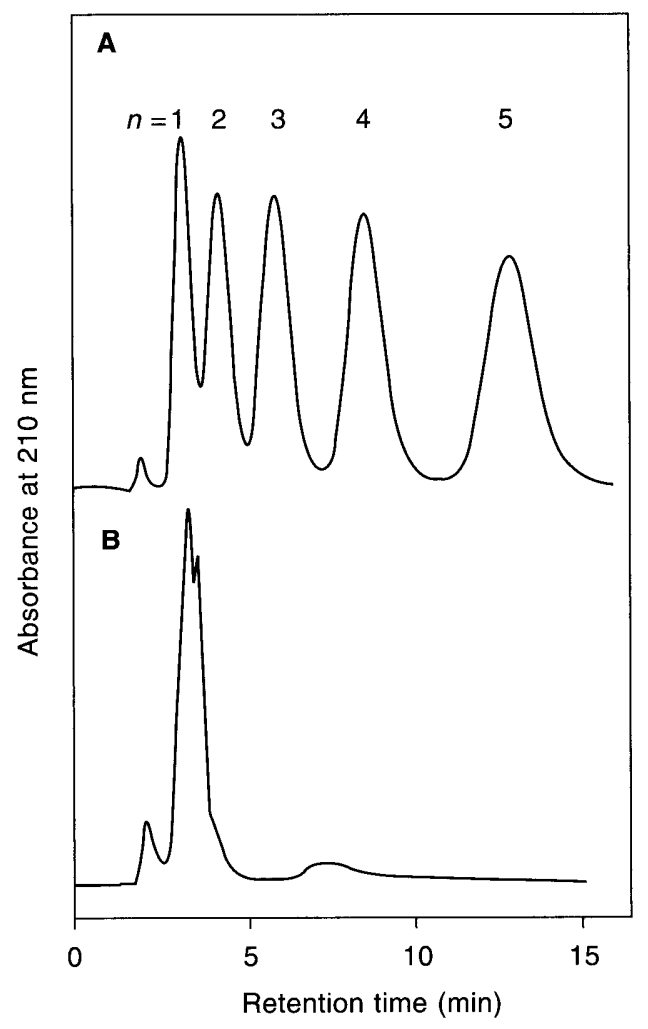

Fig. 3. HPLC chromatogram of the hydrolysate of colloidal chitin by chitinolytic enzyme from the liver of Japanese common squid. A: standard $\mathrm{GlcNAc}_{\mathrm{n}}\left(n=1\right.$ to 5). B: hydrolysate of $50 \mathrm{mg}$ colloidal chitin at $37^{\circ} \mathrm{C}$ for 24 hours.

et al., 2003). Though this ratio is in very effective for the specific production of GlcNAc, it is weak in increasing production amount. It is therefore concluded that squid liver to can be useful as a source of chitinolytic enzyme in combination with other chitinases for the enzymatic production of GlcNAc. 


\section{References}

Bradford, M. (1976). A rapid method for the quantitation of microgram quantities of protein utilizing the principle of protein-dye binding. Anal. Biochem., 72, 248-254.

Imoto, T. and Yagishita, K. (1971). A simple activity measurement of lysozyme. Agric. Biol. Chem., 35, 1154-1156.

Kajimoto, O., Sakamoto, K., Takamori, Y., Kajitani, N., Imanishi, T., Matsuo, R. and Kajitani, Y. (1998). Therapeutic activity of oral glucosamine hydrochloride in osteoarthritis of the knee: A placebocontrolled, double-blind, cross-over study. Nippon Rinsho Eiyo Gakkaishi, 20, 41-47 (in Japanese).

Kikuchi, K. (2001). Characteristics and effects of natural $N$-acetylglucosamine "Marine Sweet". Japan Fudo Saiensu, 40, 52-56 (in Japanese).

Matahira, Y. (1999). Characteristics and applications of natural $N$ acetylglucosamine as health food material. New Food Industry, 41(9), 9-13 (in Japanese).

Matsumiya, M. and Mochizuki, A. (1997). Purification and characterization of chitinase from the liver of Japanese common squid Todarodes pacificus. Fish. Sci., 63, 409-413.

Matsumiya, M., Miyauchi, K. and Mochizuki, A. (1998). Distribution of chitinase and $\beta$ - $N$-acetylhexosaminidase in the organs of a few squid and a cuttlefish. Fish. Sci., 64, 166-167.

Matsumiya, M., Miyauchi, K. and Mochizuki, A. (2002). Characterization of $38 \mathrm{kDa}$ and $42 \mathrm{kDa}$ chitinase isozymes from the liver of Japanese common squid Todarodes pacificus. Fish. Sci., 68, 603-609.

Matsumiya, M., Miyauchi, K. and Mochizuki, A. (2003). Purification and some properties of a chitinase isozyme from the liver of Japanese common squid Todarodes pacificus. Fish. Sci., 69, 427-429.

Ohtakara, A., Koga, D. and Hirano, S. (1991). Methods for mea- surement of chitinase activity. In "Experimental Manual of Chitin and Chitosan," ed. by A. Ohtakara and M. Yabuki, Gihodoshuppan, Tokyo, pp. 116-120 (in Japanese).

Ohtakara, A. (1988). Chitinase and $\beta-N$-acetylhexosaminidase from Pycnoporus cinnabarinus. In "Methods in Enzymology, Vol. 161," ed. by W.A. Wood, and S.T. Kellogg, Academic Press, New York, pp. 462-470.

Pichyangkura, R., Kudan, S., Kuttiyawong, K., Sukwattanasinitt, M. and Aiba, S. (2002). Quantitative production of 2-acetamido-2deoxy-D-glucose from crystalline chitin by bacterial chitinase. Carbohydr Res, 337, 557-559.

Sashiwa, H., Fujishima, S., Yamano, N., Kawasaki, N., Nakayama, A., Muraki, E. and Aiba, S. (2001). Production of $N$-acetyl-D-glucosamine from $\beta$-chitin by enzymatic hydrolysis. Chem. Lett., $\mathbf{4}$, 308-309.

Sashiwa, H., Fujishima, S., Yamano, N., Kawasaki, N., Nakayama, A., Muraki, E., Hiraga, K., Oda, K. and Aiba, S. (2002). Production of $N$-acetyl-D-glucosamine from $\alpha$-chitin by crude enzymes from Aeromonas hydrophila $\mathrm{H}-2330$. Carbohydr Res., 337, 761-763.

Sashiwa, H., Fujishima, S., Yamano, N., Kawasaki, N., Nakayama, A., Muraki, E., Sukwattanasinitt, M., Pichyangkura, R. and Aiba, S. (2003). Enzymatic production of $N$-acetyl-D-glucosamine from chitin. Degradation study of $\mathrm{N}$-acetylchitooligosaccharide and the effect of mixing of crude enzymes. Carbohydr. Polym., 51, 391-395.

Suguro, S., Minami, S., Kusuhara, S., Kumada, T. and Sakamoto, K. (2000). Effect of glucosamine hydrochloride on healing of cartilaginous injuries. Food Style 21, 4, 67-73 (in Japanese).

Sukwattanasinitt, M., Zhu, H., Sashiwa, H. and Aiba, S. (2002). Utilization of commercial non-chitinase enzymes from fungi for preparation of 2-acetamido-2-deoxy-D-glucose from $\beta$-chitin. Carbohydr. Res., 337, 133-137. 